\title{
Correction to: Investigating the effects of the flipped classroom model on Omani EFL learners' motivation level in English speaking performance
}

\author{
Mohamad Yahya Abdullah $^{1,2} \cdot$ Supyan Hussin $^{1} \cdot$ Kemboja Ismail $^{1}$
}

Published online: 28 June 2019

(C) Springer Science+Business Media, LLC, part of Springer Nature 2019

\section{Correction To: Education and Information Technologies https://doi.org/10.1007/s10639-019-09911-5}

The authors replace the reference to Al-Mohammadi and Derbel 2014 [1] with a new reference [2].

The authors were unaware that [1] had almost fully plagiarized [2] and wish to give full credit to the original author.

[1] RETRACTED ARTICLE: Al-Mohammadi, S., \& Derbel, E. (2014). The effects of embedding information technologies within ELT on EFL learners' motivation and interest. International Journal of Applied Linguistics and English Literature, 3(1), 181-186. http://www.journals.aiac.org.au/index.php/IJALEL/article/view/1046

[2] Lachheb, Ahmed, "Information Technology Effects on Tunisian College Students; Tunisian English Majors as a Case Study” (2013). Masters Theses. 49. https://scholarworks.gvsu.edu/theses/49

Publisher's note Springer Nature remains neutral with regard to jurisdictional claims in published maps and institutional affiliations.

The online version of the original article can be found at https://doi.org/10.1007/s10639-019-09911-5

Mohamad Yahya Abdullah

mabdullah@buc.edu.om

1 Universiti Kebangsaan Malaysia, Bangi, Malaysia

2 Buraimi Univeristy College, Al Buraimi, Sultanate of Oman 